DOI: 10.14720/aas.2016.107.2.15

Agrovoc descriptors: Essential oil crops, new technology, fertilizers, inorganic fertilizers, micronutrient fertilizers, iron, spacing, crop performance, yield components

Agris category code: F01,F04

\title{
Nano-iron fertilizer effects on some plant traits of dragonhead (Dracocephalum moldavica L.) under different sowing densities
}

\author{
Saeed YOUSEFZADEH ${ }^{1}$, Naser SABAGHNIA ${ }^{2}$
}

Received June 14, 2016; accepted September 30, 2016.

Delo je prispelo 14. junija 2016, sprejeto 30. septembra 2016.

\begin{abstract}
A field experiment was conducted with dragonhead to evaluate the effects of iron nano-fertilizer rates $(0,1,2$ and $3 \mathrm{~g}$ $\left.1^{-1}\right)$ and planting density levels $(10,15,20$ and $40 \mathrm{~cm})$ on the fresh herb, essential oil content and other traits under the natural conditions. Traits such as number of flowering branches (NFB), height of first flowering branch (HFB), number of secondary branches (NSB), stem diameter (SD), essential oil content (EOC), dry mass (DM), essential oil yield (EOY), total anthocyanins (TA), chlorophyll a (CA), chlorophyll b (CB), flavonoid $270 \mathrm{~nm}$ (F270), flavonoid $300 \mathrm{~nm}$ (F300), and total flavonoid (TF) were measured. Results showed that the nano Fe treatment $\times$ trait (TT) biplot accounted $39 \%$ and $25 \%$ of total variation, respectively. The vertex treatments in polygon biplot were D2-N2 $(15 \mathrm{~cm}$ density and $1 \mathrm{~g} \mathrm{l}^{-1}$ nano-fertilizer) was the best in the EOC, $\mathrm{DM}$ and EOY, while D4-N3 $\left(40 \mathrm{~cm}\right.$ density and $2 \mathrm{~g} \mathrm{l}^{-1}$ nanofertilizer) was the best for TA, F270, F300 and TF. Sowing densities $(10,15$ and $20 \mathrm{~cm})$ with iron nano-fertilizer treatments $\left(1\right.$ and $2 \mathrm{~g} \mathrm{l}^{-1}$ ) were the best combinations of evaluated factors for all the measured traits of the dragonhead.
\end{abstract}

Key words: dragonhead, essential oil, nano-fertilizer, planting distances

\section{IZVLEČEK}

\author{
ANALIZA NEKATERIH LASTNOSTI MOLDAVSKE \\ KAČJEGLAVKE (Dracocephalum moldavica L.) PRI \\ RAZLIČNIH ODMERKIH GNOJENJA Z NANO- \\ ŽELEZOVIMI GNOJILI IN RAZLIČNIH GOSTOTAH \\ SETVE
}

Poljski poskus z moldavsko kačjeglavko je bil izveden za ovrednotenje učinka različnih odmerkov nano železovih gnojil $\left(0,1,2\right.$ in $\left.3 \mathrm{~g} \mathrm{l}^{-1}\right)$ in gostote setve $(10,15,20$ in $40 \mathrm{~cm})$ na pridelek sveže mase, vsebnost eteričnih olj in na nekatere druge lastnosti $\mathrm{v}$ naravnih razmerah. Izmerjene so bile lastnosti, kot je število cvetočih poganjkov (NFB), višina prvega cvetočega poganjka (HFB), število sekundarnih poganjkov (NSB), premer stebla (SD), vsebnost eteričnih olj (EOC), suha masa (DM), pridelek eteričnih olj (EOY), celokupni antocianini (TA), klorofil a (CA), klorofil b (CB), flavonoidi $270 \mathrm{~nm}$ (F270), flavonoidi $300 \mathrm{~nm}$ (F300) in celokupni flavonoidi (TF). Rezultati "biplot" analize obravnavanje $\mathrm{x}$ lastnost (TT) so pojasnili $39 \%$ in $25 \%$ celokupne variabilnosti. Najboljši obravnavanji v poligonalnem biplotu sta bili D2-N2 $(15 \mathrm{~cm}$ gostota setve in 1 $\mathrm{g}^{-1}$ nano-gnojila), ki je dalo najboljše vrednosti za lastnosti EOC, DM in EOY, in obravnavanje D4-N3 $(40 \mathrm{~cm}$ gostota setve in $2 \mathrm{~g} \mathrm{l}^{-1}$ nano-gnojila), ki je dalo najboljše vrednosti za lastnosti TA, F270, F300 in TF. Za vse merjene lastnosti moldavse kačjeglavke so se kot najboljše kombinacije proučevanih dejavnikov izkazale pri gostotah setve 10,15 in $20 \mathrm{~cm}$ ter pri gnojenju z 1 in $2 \mathrm{~g} \mathrm{l}^{-1}$ nano železovih gnojil.

Ključne besede: moldavska kačjeglavka, eterična olja, nanognojila, gostota setve

\footnotetext{
Assistant Professor, Department of Agriculture, Payame Noor University, Tehran, Iran. Email: s_yousefzadeh@pnu.ac.ir

2 Department of Agronomy and Plant Breeding, Faculty of Agriculture, University of Maragheh, Maragheh, Iran. Email: sabaghnia@maragheh.ac.ir
} 


\section{INTRODUCTION}

The Dragonhead (Dracocephalum moldavica L.) is a perennial herbaceous plant up to $80 \mathrm{~cm}$ tall and grows at altitudes of up to 2700-3100 m above sea level; it also is grown for its essential oil and for bees (Popova et al., 2008). It is native to central Asia and is domesticated in Europe and is used as a food ingredient, as a tea, as the herbal drug for its reputed medicinal properties (Dastmalchi et al., 2007). The leaves of the dragonhead are opposed, long and oval in shape on the long petioles and its flowers, on short pedicles, are blue-violet in color. It contains terpenoids and flavonoids and its extracts from the raw material have a multitude of pharmacological actions and the used material consisted of dragonhead herb are prepared at different growth phases of vegetative growth, flowering, and maturity (Nikitina et al., 2008).

Environmental factors affect the content and composition of secondary metabolites of medicinal plants and it is generally assumed that the material is best collected when the plants have reached their optimal growth (Aziz et al., 2010). Plant density is one of the important factor which determines growth, development and yield of medicinal plants and its selection to allow for expression of maximum yield performance is a management practice that would make medicinal plants production more economical (Hussein et al., 2006). Cultivation of crops with desirable density has positive effect on yield components, so this factor should be suitable to achieve optimum plant density and maintenance of optimum growth. Low plant density results in high weeds population and low yield performance, while dense plant population on the other hand causes lodging, reduces photosynthetic production and drastically reduces the yield performance (Soroori et al., 2014).

Nutrients have a great effect on yield performance and chemical composition of medicinal plants (Heidari et al., 2011), and microelements have an important role in their production (Hopkins and Huner, 2004). A balanced fertilization with micronutrients is very important issue in the high yield performance as well as high quality essential oil (Sawan et al., 2001), and for sufficient plant growth, some micronutrients are required in small amounts; however, their deficiencies cause a great negative effect in the biochemical reactions (Bacha et al., 1997). Plants absorb nutrients from soils via roots although nutrients can be supplied to plants as fertilizers by foliar sprays. There is little information on the response of dragonhead to applied nutrients, particularly of micronutrients and iron $(\mathrm{Fe})$ which is a cofactor for approximately more than hundred enzymes that catalyze physiological processes (Brittenham, 1994). The alkaline nature of most soils of semi-arid environments predisposes to Fe deficiency, so that crops usually suffer from short supply of this nutrient and it has been reported that iron foliar application increased the yield performance of medicinal plants (Ebrahimzadeh et al., 2009; Nasiri et al., 2010; Jabbari et al., 2011).

Nanotechnology is a novel science that atracts researchers from different disciplines such as biologists across the globe and nanoparticles are aggregates with at least one dimension less than $100 \mathrm{~nm}$, which can modify their properties compared to the bulk material (Tarafdar et al., 2014). Owing to its high ratio of surface area to volume they exhibit novel and improved properties and functions and the nano-fertilizers have a slower release compared to the conventional fertilizer application, which release heavily early and in low non-uniform amounts (Raliya and Tarafdar, 2013). They will prevent undesirable nutrient losses to environment (soil, water and air) via direct delivery to plants, and avoiding the interaction with soil, microorganisms, water, and air (De Rosa et al., 2010). The aim of the present study was to investigate the effects of different concentrations of iron nano-chelate fertilizer and various sowing densities of Dracocephalum moldavica L. on yield and yield components, as well as the content of essential oils obtained from this plant. 


\section{MATERIALS AND METHODS}

This research was conducted in the 2014/2015 growing season at the experiment field of the college of Agriculture, Payam Noor University of Marand (latitude: $38 \circ 25^{\circ} \mathrm{N}$, longitude: $45^{\circ} 46^{\circ} \mathrm{E}$ : $1334 \mathrm{~m}$ ) in the northwest part of Iran. Precipitation falls in winter as snow on the mountains of the north and west and rainfall mainly occurs between November to May and the soil of the field was silty loam with $\mathrm{pH} \mathrm{7.8,} \mathrm{and} \mathrm{the} \mathrm{other} \mathrm{physical} \mathrm{and}$ chemical properties of soil (Table 1) were determined using the methods of Chapman and Pratt (1978). A factorial experiment based on a randomized complete block design with three replications was used with four levels of iron nanofertilizer $\left(0,1,2\right.$ and $\left.3 \mathrm{~g} \mathrm{l}^{-1}\right)$ and four plant spacing $(10,15,20$ and $40 \mathrm{~cm})$. The morphological characterization of iron nano-chelate particles were determined by scanning electron microscope (Fig. $1)$.

The seeds of Dracocephalum moldavica L. were sown directly in field on 23 May and four levels of iron nano-fertilizer were applied in 23 June. After two weeks from sowing, the plants were thinned twice, leaving one plant in hills. Irrigation and manually weeds' control were performed when needed. The plants were collected at full flowering stage in 24 July, and the following data were recorded for plant growth characters: number of flowering branches (NFB), height of first flowering branch (HFB), number of secondary branches (NSB), stem diameter (SD), essential oil content (EOC), dry mass (DM), essential oil yield (EOY), total anthocyanins (TA), chlorophyll a (CA), chlorophyll b (CB), flavonoid $270 \mathrm{~nm}$ (F270), flavonoid $300 \mathrm{~nm}$ (F300), and total flavonoid (TF). Chlorophyll a and $\mathrm{b}\left(\mathrm{mg} \mathrm{g}^{-1}\right)$ of the leaves were determined by AOAC (1990) and the resulted essential oil from each treatment was dehydrated over anhydrous sodium sulfate and then subjected to GLC analysis with Varian VISTA 6000 FID model. The two-way matrix of treatment $\times$ trait interaction is consisted of 16 treatment combinations (4 iron nano-fertilizer $\times 4$ sowing density) which is analyzed by the treatment $\times$ trait (TT) biplot model (Yan and Rajcan, 2002). Visual analysis of dataset via TT biplot was performed using GGEbiplot software (Yan, 2001) and all biplots presented in this paper are direct outputs of this statistical software. Up-to-date information on GGE biplot is available at http://www.ggebiplot.com.

Table 1. Pearson's simple correlation coefficients among the Dragonhead traits

\begin{tabular}{lcccccccccccc}
\hline & NFB & HFB & NSB & SD & EOC & DW & EOY & TA & CA & CB & F270 & F300 \\
\hline HFB & -0.27 & & & & & & & & & & & \\
NSB & 0.11 & -0.05 & & & & & & & & & & \\
SD & 0.24 & -0.37 & 0.70 & & & & & & & & & \\
EOC & -0.52 & 0.27 & -0.08 & -0.14 & & & & & & & & \\
DW & -0.45 & 0.35 & -0.34 & -0.55 & 0.37 & & & & & & & \\
EOY & -0.53 & 0.39 & -0.23 & -0.45 & 0.71 & 0.91 & & & & & & \\
TA & -0.34 & -0.28 & -0.32 & -0.16 & 0.04 & 0.04 & 0.00 & & & & & \\
CA & 0.15 & -0.50 & 0.18 & -0.03 & 0.12 & -0.01 & 0.07 & 0.15 & & & & \\
CB & 0.17 & -0.38 & 0.02 & -0.25 & -0.05 & 0.00 & 0.01 & 0.19 & 0.92 & & & \\
F270 & -0.20 & -0.13 & -0.14 & -0.32 & 0.39 & 0.17 & 0.32 & 0.21 & 0.71 & 0.76 & & \\
F300 & -0.30 & -0.10 & -0.28 & -0.38 & 0.57 & 0.25 & 0.44 & 0.16 & 0.67 & 0.65 & 0.86 & \\
TF & -0.28 & -0.16 & -0.31 & -0.43 & 0.45 & 0.30 & 0.43 & 0.37 & 0.72 & 0.77 & 0.93 & 0.92 \\
\hline
\end{tabular}

Traits are: number of flowering branches (NFB), height of first flowering branch (HFB), number of secondary branches (NSB), stem diameter (SD), essential oil content (EOC), dry mass kg ha ${ }^{-1}$ (DM), essential oil yield (EOY), total anthocyanins (TA), chlorophyll a (CA), chlorophyll b (CB), flavonoid $270 \mathrm{~nm}$ (F270), flavonoid $300 \mathrm{~nm}$ (F300), total flavonoid (TF). 


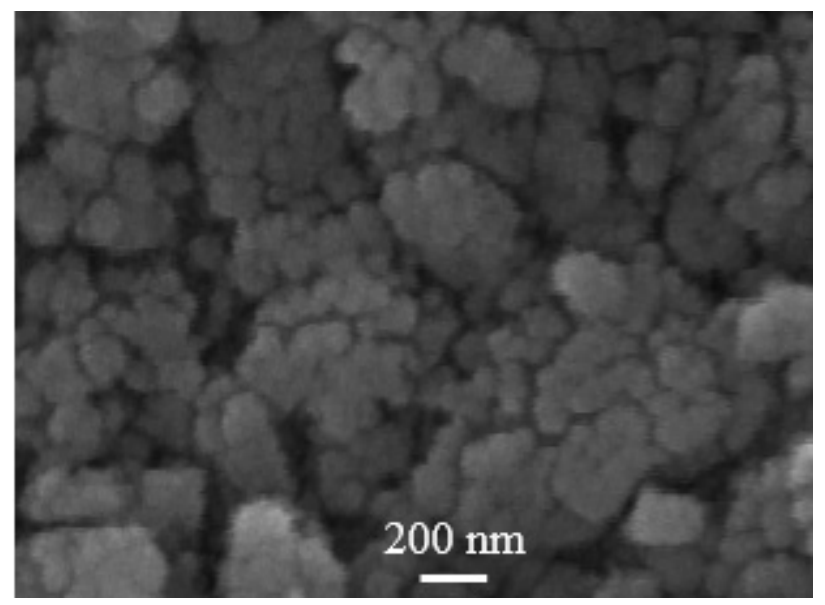

Figure 1: Scanning Electron Microscope (SEM) image of synthesized nanoparticles ferric oxide for iron nanofertilizer

\section{RESULTS AND DISCUSSION}

The TT biplot of mean performance of dragonhead treatment combinations (nano-iron fertilizer $\times$ sowing density) explained $64 \%$ of the total variation of the standardized data (Fig. 2A) and this relatively moderate percentage variation reflects the accuracy of interrelationships among the measured traits across different treatment combinations. According to Kroonenberg (1995), the fundamental patterns of complicated relations among the traits and treatment combinations should be captured by the biplot analysis. Fig. 2A is biplot showing the polygon view of the treatment $\times$ trait analysis on the morphological and other measured traits based on principal component (PC) axes (PC1 and $\mathrm{PC} 2)$. The traits were considered as the tester and the treatment combinations as entries. The first two axes explained 39 and $25 \%$ of the total variation among the treatment due to morphological traits measured, respectively. This figure shows which treatment(s) were best at what trait. The treatment (s) at each vertex (vertex treatment) of the polygon were the best in terms of the trait(s) found within the sector demarcated by any two lines that meet at the origin. From Fig. 2A, D2-N2 (15 cm planting density and $1 \mathrm{~g} \mathrm{l}^{-1}$ iron nano-fertilizer) was the best in terms of essential oil content (EOC), dry mass (DM) and essential oil yield (EOY), indicating that it can be used in the high production of dragonhead plants that are outstanding in these traits.
The vertex treatment combination D4-N3 $(40 \mathrm{~cm}$ planting density and $2 \mathrm{~g} \mathrm{l}^{-1}$ iron nano-fertilizer) was the best treatment for obtaining of the total anthocyanins (TA), flavonoid $270 \mathrm{~nm}$ (F270), flavonoid $300 \mathrm{~nm}$ (F300) and total flavonoid (TF) while the vertex treatment combination D4-N1 (40 $\mathrm{cm}$ planting density and $0 \mathrm{~g} \mathrm{l}^{-1}$ iron nano-fertilizer) was the best treatment for obtaining of the number of secondary branches (NSB) and stem diameter (SD). Even though D4-N3 was identified for good performance in anthocyanins and flavonoid traits, it was not the best for EOC, DW and EOY traits, indicating that the content of the anthocyanins and flavonoid traits might not be a good trait-indicators for yield and essential oil of dragonhead. The vertex treatment combination D3-N1 $(20 \mathrm{~cm}$ planting density and $0 \mathrm{~g} \mathrm{l}^{-1}$ iron nano-fertilizer) was identified for good performance in height of first flowering branch (HFB) trait while the vertex treatment combination D4-N2 $(40 \mathrm{~cm}$ planting density and $1 \mathrm{~g} \mathrm{l} \mathrm{l}^{-1}$ iron nano-fertilizer) was identified for good performance in number of flowering branches (NFB) trait (Fig. 2A). The enhancing effect of iron nano-fertilizer on chlorophyll content and yield performance could be attributed to the favorable effect of iron nanofertilizer treatments to increase biosynthesis of chlorophylls which are involved in chloroplast biosynthesis, which might be expected as a reason for chlorophyll increases in dragonhead leaves (Marschner, 2012). 
On this premise, two traits are positively correlated if the angle between their vectors is an acute angle $\left(<90^{\circ}\right)$ while they are negatively correlated if their vectors is an obtuse angle $\left(>90^{\circ}\right.$ ) (Yan and Kang, 2003). Across the 16 tested treatments combinations, DM, EOY and EOC were positively associated (an acute angle) as shown in Fig. 2B. These traits were negatively correlated with $\mathrm{SD}$, NSB and NFB traits (obtuse angles), and they were independent of the $\mathrm{CA}$ and $\mathrm{CB}$ traits (near right angles).These relationships suggest that it is possible to combine higher dry yield, higher essential oil content and higher essential oil in a single treatments combination (Fig. 2B). Traits F300, TF, F270 and TA were positively associated (an acute angle), and they were independent of the HFB trait (near right angles), while CA and CB traits were positively associated (an acute angle), and they were independent of the SD, NSB and

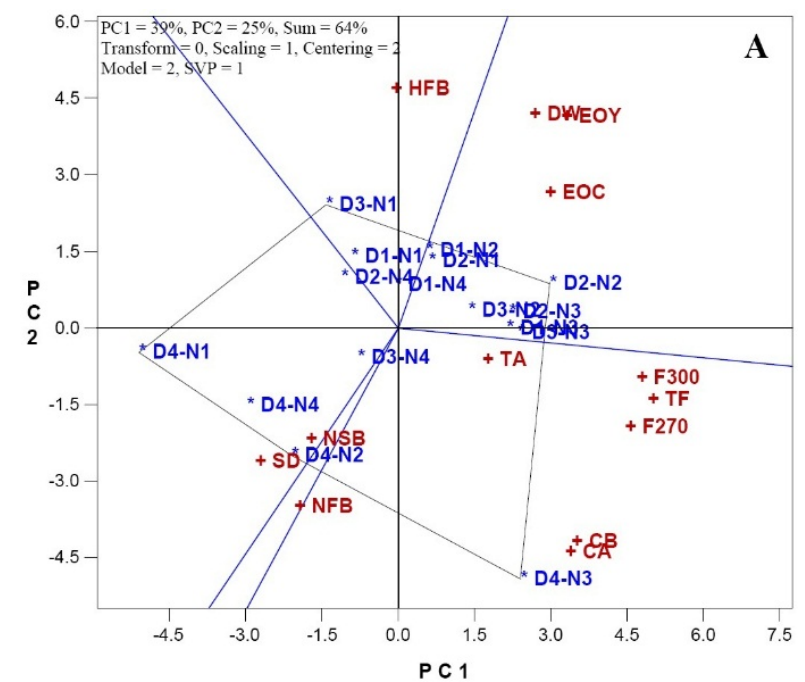

Figure 2: (A) Polygon view of the genotype-by-trait (TT) biplot on traits of the Dragonhead showing the whichwon-where pattern and (B) Vector view of the TT biplot showing the interrelationships among all traits.

In the context of treatment-by-trait analysis, an ideal treatment has been defined as the treatment that combines several good traits in its property and it should possess the highest mean performance across traits (i.e., longest projection onto the average tester coordinate (ATC) axis and shortest entry-vector, thus, it should be close to the ideal treatment represented by the innermost concentric circle with an arrow pointing to it (Yan and Kang, 2003). Such ideal treatment can, therefore, be used as a reference check in subsequent trials where the set of traits will be
NFB traits (near right angles). Finally, SD, NSB and NFB traits were positively associated (an acute angle) as shown in Fig. 2B. According to Rahbarian and Salehi-Sardoei (2014) there is strong positive correlation between dry mass of dragonhead with number of branches per plant, plant height while it was or non-significantly correlated with diameter and length of stem internode. Although most of the above predictions can be verified from the Pearson's correlation coefficients (Table 1), but some others are not consistent with the original coefficients of correlation because such discrepancies are seen because the TT biplot method explained lower than $100 \%$ (in present study, 64\%) of the total variation. In other word, some information were ignored by using TT biplot method, but major pattern of dataset is interpreted easily via visual grasp.

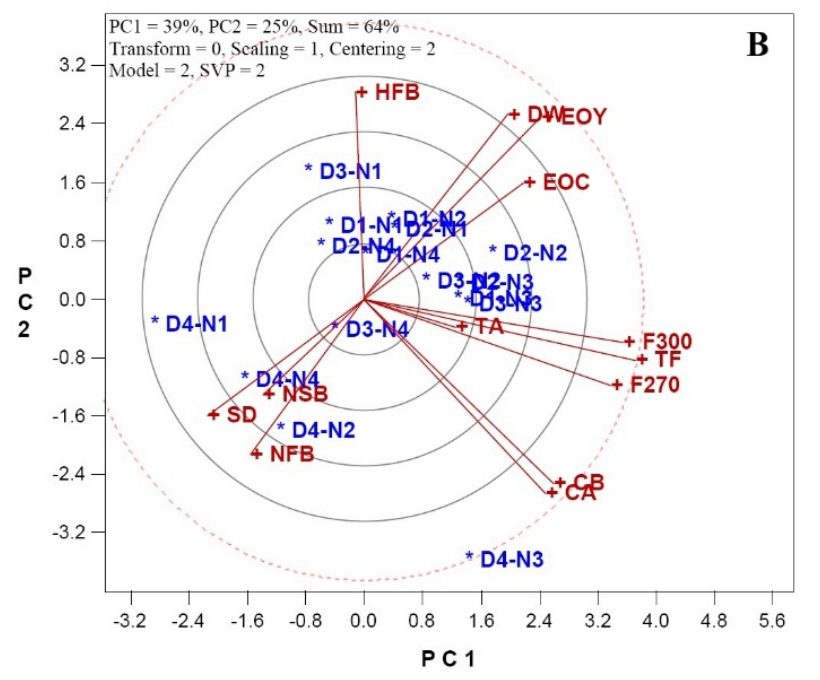


D2-N1, D2-N2, D2-N3, D3-N2, D3-N3, and D4N3, while the other treatment combinations (D1N1, D1-N4, D2-N4, D3-N1, D3-N4, D4-N1, D4$\mathrm{N} 2$ and) performed below average in terms of measured parameters (Fig. 3A). It seems that moderate or small sowing densities $(10,15$ and 20 $\mathrm{cm})$ and moderate iron nano-fertilizer treatments (1 and $2 \mathrm{~g} \mathrm{l}^{-1}$ ) had the most favorable impact on the measured traits of the dragonhead. In other word, high concentration of iron nano-fertilizer as well as wide sowing spaces had negative effect on dragonhead. Five treatment combinations (D1-N3, D2-N2, D2-N3, D3-N2 and D3-N3) were the closest to the position of an ideal treatment which is ranked the highest in term of traits' performance

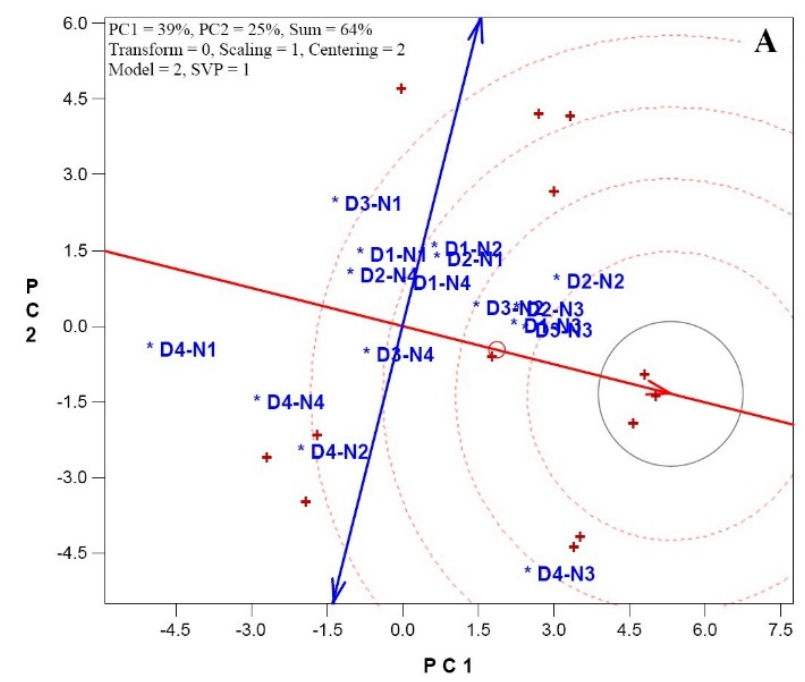

because it is desirable in terms of most of the traits (Fig. 3A).

In the context of TT biplot analysis, an ideal tester of trait has been defined as the tester that combines several good treatments in its composition (Baljani et al., 2015) and according to Fig. 3B, the ideal trait was strongly related to flavonoid related traits (F270, F300 and TF) followed by TA, CA and CB traits. Flavonoids have been reported in the flowering parts of dragonhead and its extracts could be due to phenolic compounds that are present in this plant and it is well established that flavonoids are remarkable for their antioxidant activities (Povilaityee and Venskutonis, 2000).

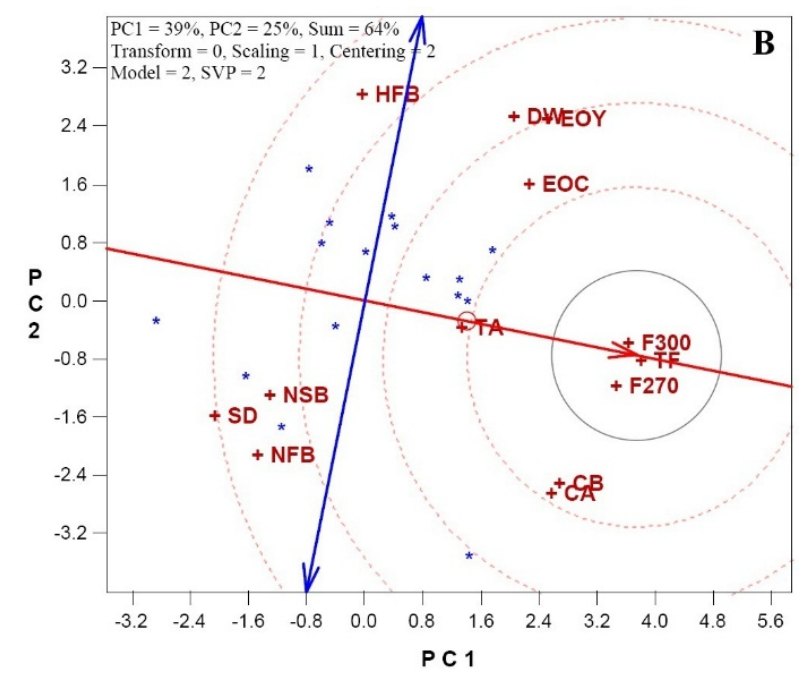

Figure 3: (A) Ideal entry view of TT biplot, showing the relationships of different treatment combinations with ideal entry and (B) ideal tester view of the TT biplot, showing the relationships of different traits with ideal tester.

Due to large importance of yield performance in dragonhead production, this trait was compared visually under the studied treatments and displayed in Fig. 4A and in the context of TT biplot, the best treatment combination for obtaining of dry mass (DM) could be find. A vector-view function shows treatments that have close association with a target trait among other traits and according to this biplot of (Fig. 4A), D2-N2 (15 cm planting density with 1 $\mathrm{g}^{-1}$ iron plus nano-fertilizer) treatment was the best treatment suitable for obtaining of high DM. Thus, application of this treatment combination is expected to lead to improved target trait (DM) under studied growing conditions. Similarly, due to importance of essential oil yield (EOY), it was compared in the studied via above biplot tool and declared that the best treatment combination for obtaining of high magnitudes of EOY is D2-N2 (15 $\mathrm{cm}$ planting density with $1 \mathrm{~g} \mathrm{l}^{-1}$ iron plus nanofertilizer) as the best treatment (Fig. 4B). This suggests that using iron nano-sized micronutrient fertilizer plus $15 \mathrm{~cm}$ sowing space will not only result in the development of high dry mass of the dragonhead but also causes to obtain the other desirable traits like essential oil yield. Amirnia et al. (2014), have emphasized the positive effects of iron micronutrient nano-fertilizer on saffron production. Several investigators mentioned similar results on different crops such as El-Desuki et al. (2001) on sweet fennel, Khalil and ElSherbeny (2003) on mint, and Hussein et al. (2006) on dragonhead, who observed that application of different macro and micro-nutrients significantly improved plant growth characters. This result may 
be due to effect of iron nano-fertilizer on accelerating metabolism reactions as well as stimulating enzymes. This increment may be due to the effect of iron nano-fertilizer on mass production or/and oil content. Concerning the effect of plant sowing density on essential oil of dragonhead, wider spaces offer ample quantity of nutrients, light and other environmental factors which in turn was reflected on the high amounts of morphological traits and essential oil content.

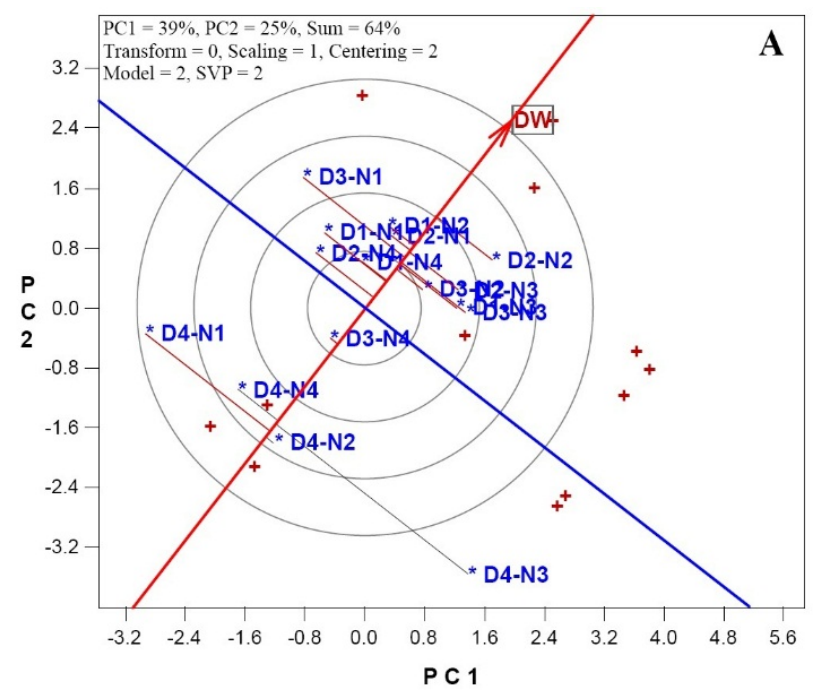

For all 38 , or $25.5 \%$ of regenerants that were transferred to the non-selective medium, molecular Results of present investigation indicate that the polygon-view as well as vector-view of TT biplot are the best tools for visualizing the interaction pattern among treatments and traits. One of the most important applications of nanotechnology in agriculture is using nano-fertilizers for plant nutrition while comparing it to the conventional application of fertilizers there is huge difference in the accuracy, smart nature, effectiveness, cost for operation, ease of construction and many others.

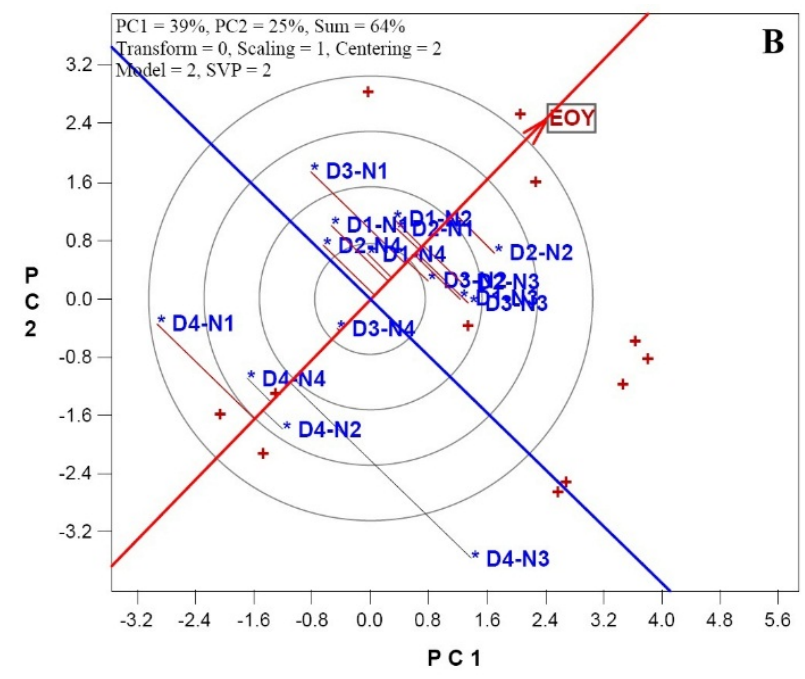

Figure 4: (A) Vector view of treatment by trait (TT) biplot, showing the relationships of different treatment combustions with target trait (DM, dry mass), and (A) Vector view of treatment by trait (TT) biplot, showing the relationships of different treatment combustions with target trait (EOY, essential oil yield).

\section{CONCLUSIONS}

This study indicated that application of $1 \mathrm{~g}^{-1}$ iron nano-fertilizer plus $15 \mathrm{~cm}$ planting space increase the dragonhead's dry mass yield and essential oil yield cultivated in semiarid region conditions.
Also, treatment by trait (TT) biplot is an excellent statistical tool for interpreting the interaction pattern of agriculture studies.

\section{ACKNOWLEDGEMENT}

The current paper is extracted from research project entitled "Effect of nano-iron fertilizer and plant density on quantitative and qualitative traits of dragonhead" which was financial supported by Research Grant from Payame Noor University,
Tehran, Iran. We wish to thank Dr. Weikai Yan for making available a time-limited version of GGEbiplot. Also, we thank two anonymous reviewers for their valuable comments and suggestions. 


\section{REFERENCES}

Afolabi A.S. 2007. Status of clean gene (selection marker-free) technology. African Journal of Biotechnology, 6: 2910-2923, doi: 10.5897/AJB2007.000-2460

Atkinson R.G., Gardner R.C. 1991. Agrobacteriummediated transformation of pepino and regeneration of transgenic plants. Plant Cell Reports, 10: 208212, doi: 10.1007/BF00234297

Atkinson R.G., Gardner R.C. 1993. Regeneration of transgenic tamarillo plants. Plant Cell Reports, 12: 347-351, doi: 10.1007/BF00237433

Cambia. 1997. pCAMBIA vector release manual version 3.05. Camberra, Center for the application of molecular biology to international agriculture: 6 p.

CERA. 2012. GM crop database. Center for Environmental Risk Assessment (CERA). Washington D.C. ILSI Research Foundation http://cera-

gmc.org/index.php?action=gm_crop_database

Cheng Z.M., Schnurr J.A., Kapaun J.A. 1998. Timentin as an alternative antibiotic for suppressin of Agrobacteriu tumefaciens in genetic transformation. Plant Cell Reports, 17: 646-649, doi: $10.1007 / \mathrm{s} 002990050458$

Gelvin S.B. 2003. Agrobacterium-mediated plant transformation: the biology behind the "genejockeying tool". Microbiology and Molecular Biology Reviews, 67: 16-37, doi: 10.1128/MMBR.67.1.16-37.2003

Gleave A.P. 1992. A versatile binary vector system with a T-DNA organisational structure conducive to efficient integration of cloned DNA into the plant genome. Plant Molecular Biology, 20: 1203-1207, doi: 10.1007/BF00028910

Fisher D.K., Guiltinan M.J. 1995. Rapid, efficient production of homozygous transgenic tobacco plants with Agrobacterium tumefaciens: a seed-toseed protocol. Plant Molecular Biology Reporter, 13, 3: 278-289, doi: 10.1007/BF02670906

Fuchs R.L., Ream J.E., Hammond B.G., Naylor M.W., Leimgruber R.M., Berberich S.A. 1993. Safety assessment of the neomycin phosphotransferaseII (NPTII) protein. Bio/Technology 11: 1543-1547, doi: $10.1038 /$ nbt1293-1543

Harper B.K., Mabon S.A., Leffel S.M., Halfhill M.D., Richards H.A., Moyer K.A., Stewart C.N. 1999. Green fluorescent protein as a marker for expression of a second gene in transgenic plants.
Nature Biotechnology, 17: 1125-1129, doi: $10.1038 / 15114$

Haseloff J., Amos B. 1995. GFP in plants. Trends in Genetics 11: 328-329, doi: 10.1016/01689525(95)90186-8

Haseloff J., Siemering K.R., Prasher D.C., Hodge S. 1997. Removal of a cryptic intron and subcellular localization of green fluorescent protein are required to mark transgenic Arabidopsis plants brightly. Proceedings of the National Academy of Science of the United States of America, 94: 21222127, doi: 10.1073/pnas.94.6.2122

Hiei Y., Ohta S., Komari T., Kumashiro T. 1994. Efficient transformation of rice (Oryza sativa L.) mediated by Agrobacterium and sequence analysis of the boundaries of the T-DNA. Plant Journal, 6: 271-282, doi: 10.1046/j.1365313X.1994.6020271.x

Hiei Y., Komori T., Kubo T. 1997. Transformation of rice mediated by Agrobacterium tumefaciens. Plant Molecular Biology, 35: 205-218, doi: 10.1023/A:1005847615493

Horsch R.B., Fraley R.T., Rogers S.G., Sanders P.R., Lloyd A., Hoffmann N. 1984. Inheritance of functional foregin genes in plants. Science, 223: 496-498, doi: 10.1126/science.223.4635.496

Horsch R.B., Fry J.E., Hoffmann N.L., Eichholtz D., Rogers S.G., Fraley R.T. 1985. A simple and general method for transferring genes into plants. Science, 227: 1229-1231, doi: 10.1126/science.227.4691.1229

Jach G., Binot E., Frings S., Luxa K., Schell J. 2001. Use of red fluorescent protein from Discosoma sp. (dsRED) as a reporter for plant gene expression. The Plant Journal, 28: 483-491, doi: 10.1046/j.1365-313X.2001.01153.X

Kump B., Svetek S., Javornik B. 1992. Izolacija visokomolekularne DNA iz rastlinskih tkiv. Zbornik Biotehniške fakultete Univerze v Ljubljani - Kmetijstvo, 59: 63-66

Lakshmi Sita G., Sreenivas G.L., Bhattacharya A. 1998. Agrobacterium mediated transformation of sandalwood (Santalum album L.) a tropical forest tree. Plant Tissue Culture and Biotechnology, 4, 34: 189-195

Lippincott-Scgwartz J., Patterson G.H. 2003. Development and use of fluorescent protein markers in living cells. Science, 300, 5616: 87-91, doi: $10.1126 /$ science. 1082520 
Mann D.G.J., Abercrombie L.L., Rudis M.R., Millwood R.J., Dunlap J.R., Stewart C.N. 2012. Very bright orange fluorescent plants: endoplasmatic reticulum targeting of orange fluorescent proteins as visual reporters in transgenic plants. BMC Biotechnology, 12: $17 \mathrm{p}$.

Matz M.V., Fradkov A.F., Labas Y.A., Savitsky A.P., Zaraisky A.G., Markelov M.L., Lukyanov S.A. 1999. Fluorescent proteins from nonbiluminescent Anthozoa species. Nature Biotechnology, 17: 969973, doi: 10.1038/13657

Mercuri A., De Benedetti L., Burchi G., Schiva T. 2000. Agrobacterium-mediated transformation of African violet. Plant Cell, Tissue and Organ Culture, 60: 39-46, doi: 10.1023/A:1006457716959

Miki B., McHugh S. 2004. Selectable marker genes in transgenic plants: applications, alternatives and biosafety. Journal of Biotechnology, 107: 193-232, doi: 10.1016/j.jbiotec.2003.10.011

Murashige T., Skoog H. 1962. A revised medium for rapid growth and bioassays with tobacco tissue cultures. Physiologia Plantarum, 15: 473-479, doi: 10.1111/j.1399-3054.1962.tb08052.x

Nauerby B., Billing K., Wyndaele R. 1996. Influence of the antibiotic timentin on plant regeneration compared to carbenicillin and cefotaxime in concentrations suitable for elimination of Agrobacterium tumefaciens. Plant Science, 123: 169-177, doi: 10.1016/S0168-9452(96)04569-4

Park S.H., Rose S.C., Zapata C., Srivatanakul M., Smith R.H. 1998. Cross-protection and selectable marker genes in plant transformation. In Vitro Cellular and Developmental Biology Plant, 34, 2: 117-121, doi: 10.1007/BF02822775

Rao A.Q., Bakhsh A., Kiani S., Shahzad K., Shahid A.A., Husnain T., Riazuddin S. 2009. The myth of plant transformation. Biotechnology Advances, 27: 753-763, doi: 10.1016/j.biotechadv.2009.04.028

Reichel C., Mathur J., Ecke P., Langenkemper K., Koncz C., Schell J., Reiss B., Maas C. 1996. Enhanced green fluorescence by the expression of an Aequorea victoria green fluorescent protein mutant in mono- and dicotyledonous plant cells. Proceedings of the National academy of Sciences of the United States of America, 93: 5888-5893, doi: 10.1073/pnas.93.12.5888

Stewart C.N. 2005. Monitoring the presence and expression of transgenes in living plants. Trends in Plant Science, 10: 390-396, doi: 10.1016/j.tplants.2005.06.003

Stolarz A., Macewicz J., Lörz H. 1991. Direct somatic embryogenesis and plant regeneration from leaf explants of Nicotiana tabacum L. Journal of Plant Physiology, 137: 347-357, doi: 10.1016/S01761617(11)80144-6

Sunilkumar G., Vijayachandra K., Veluthambi K. 1999. Preincubation of cut tobacco leaf explants promotes Agrobacterium-mediated transformation by increasing vir gene induction. Plant Science, 141: 51-58, doi: 10.1016/S0168-9452(98)00228-3

Škof S. 2008. Izražanje markerskih genov pri hmelju (Humulus lupulus L.) in tobaku (Nicotiana tabacum L.). Doktorska disertacija. Ljubljana, Biotehniška fakulteta, Oddelek za agronomijo: $119 \mathrm{p}$.

Witty M., 1989. Thaumatin II: a simple marker gene for use in plants. Nucleic Acids Research, 17: 3312, doi: 10.1093/nar/17.8.3312

Yao J.L., Cohen D., Atkinson R., Richardson K., Morris B. 1995. Regeneration of transgenic plants from the commercial apple cultivar Royal Gala. Plant cell Reports, 14: 407-412,doi: 10.1007/BF00234044 